\title{
INVESTIGATION OF PROCESS OF BIODIESEL PRODUCTION FROM TECHNICAL FATS
}

\author{
M. M. Mushtruk \\ National University of Life and Environmental Sciences of Ukraine, Ukraine. \\ Corresponding author: mixej.1984@ukr.net \\ Article history: Received: March 2019. Received in the revised form: April 2019. Accepted: May 2019. \\ Bibl. 10, fig. 5, tabl. 0 .
}

Abstract. Pre-cleaned technical animal fats are harmful to health, as they are not environmentally friendly and not suitable for recycling. The best solution is to use them for industrial purposes, namely the conversion to biodiesel. The purpose of this study is to improve the technology for the production of biodiesel from industrial animal fats under laboratory conditions and to conduct tests on the obtained samples. The most important operations of the process of obtaining biodiesel from animal waste fats are considered. The influence of the quality of fatty raw materials on the composition of liquid biodiesel has been evaluated and initial requirements for raw materials have been developed. It has been established that the moisture content of the raw material has a decisive influence on the mechanism of the transesterification of triglycerides into fatty acid methyl esters, which, according to their performance, are close to petroleum diesel fuel. Free fatty acids in raw materials in combination with water make the process ineffective. As a result of scientific research, the technology of production of biodiesel from waste vegetable oils and animal fats has been substantiated and its hardware has been proposed. According to the results of laboratory studies, the possibility of obtaining a quality product that meets modern operational requirements for biodiesel, which can be used in engines without significant reequipment, is established.

Key words: biodiesel, technical animal fats, raw materials, esterification, separation, transesterification, alternative energy resources, production technology, standard.

\section{Introduction}

Technical animal fats have always been an environment problem in food factories. Converting the technical animal fats (TAF) into biodiesel will reduce this problem. This project will not only save environment but also cost.

Biodiesel is an alternative diesel fuel derived from vegetable oils or animal fats. The main components of vegetable oils and animal fats are triglycerides or also known as ester of fatty acid attached to glycerol. One of the main driving force for biodiesel widespread is the greenhouse gas emission $\left(\mathrm{CO}_{2}\right.$ being the major one). The term TAF refers to vegetable oil has been in food production and which is no longer viable for its intended use. TAF arises from many different sources, including domestic, commercial and industrial. TAF is a potentially problematic waste stream which requires proper management. The disposal of TAF can be problematic when disposed incorrectly [1-4, 7-10].

Any fatty acid sources may be used to produce biodiesel. Therefore, any animal or plant lipid should be ready substrate for the production of biodiesel. The use of edible vegetable oils and animal fats for biodiesel production has recently been of great concern because they compete with food material- the food versus fuel dispute. There are concern that biodiesel feedstock may compete with food supply in the long term. From an economic point of view; the production of biodiesel is very feedstock sensitive. The cost of feedstock accounted for $88 \%$ of total estimated production cost. In all cases, more than $80 \%$ of the production cost is associated with the feedstock, such as recycled cooking oils. Reusing of these waste greases not only reduce the burden of the government in disposing the waste, maintaining public sewers, and treating the oily wastewater, but also lower the production cost of biodiesel significantly [1, 5-10].

\section{Analysis of recent research results}

This project is aimed to develop a simple small plant to process the technical animal fats to biodiesel and use it in the factory $[1,2,7,10]$.

Feedstock technical animal fats. Biodiesel can be produced from any material that contains fatty acids, be they linked to other molecules or present as free fatty acids. Thus various vegetable fats and oils, animal fats, waste greases, and edible fats processing wastes can be used as feed stocks for biodiesel production. The choice of feedstock is based on such variables as local availability, cost, government support and performance as a fuel. The primary feedstock is a vegetable oil or animal fat, biodiesel is generally considered to be renewable. Since the carbon in the oil or fat originated mostly from carbon dioxide in the air, biodiesel is considered to contribute much less to global warming than fossil fuels. Diesel engines operated on biodiesel have lower emissions of carbon monoxide, unburned hydrocarbons, particulate matter, and air toxics than when operated on petroleum-based diesel fuel [3, 7-10]. 
Biodiesel from technical animal fats (TAF) can reduce the cost of biodiesel production since the feedstock costs constitutes approximately $70-95 \%$ of the overall cost of biodiesel production [6]. Although biodiesel cannot entirely replace petroleum-based diesel fuel, there are at least five reasons that justify its development.

- It provides a market for excess production of vegetable oils and animal fats.

- It decreases, although will not eliminate, the country's dependence on imported petroleum.

- Biodiesel is renewable and does not contribute to global warming due to its closed carbon cycle. A life cycle analysis of biodiesel showed that overall $\mathrm{CO}_{2}$ emissions were reduced by $78 \%$ compared with petroleum-based diesel fuel $[7,10]$.

- The exhaust emissions of carbon monoxide, unburned hydrocarbons, and particulate emissions from biodiesel are lower than with regular diesel fuel. Unfortunately, most emissions tests have shown a slight increase in oxides of nitrogen $\left(\mathrm{NO}_{\mathrm{x}}\right)$. When added to regular diesel fuel in an amount equal to $1-2 \%$, it can convert fuel with poor lubricating properties, such as modern ultra-low-sulfur diesel fuel, into an acceptable fuel $[7,10]$.

\section{Results of research}

Fig. 1 describes the steps, processes and methods used to produce biodiesel product. This process started from free fatty acid to determine acid value and step of process. Second process is drying to remove water in FAME and last process is properties physical to determine contents of FAME.

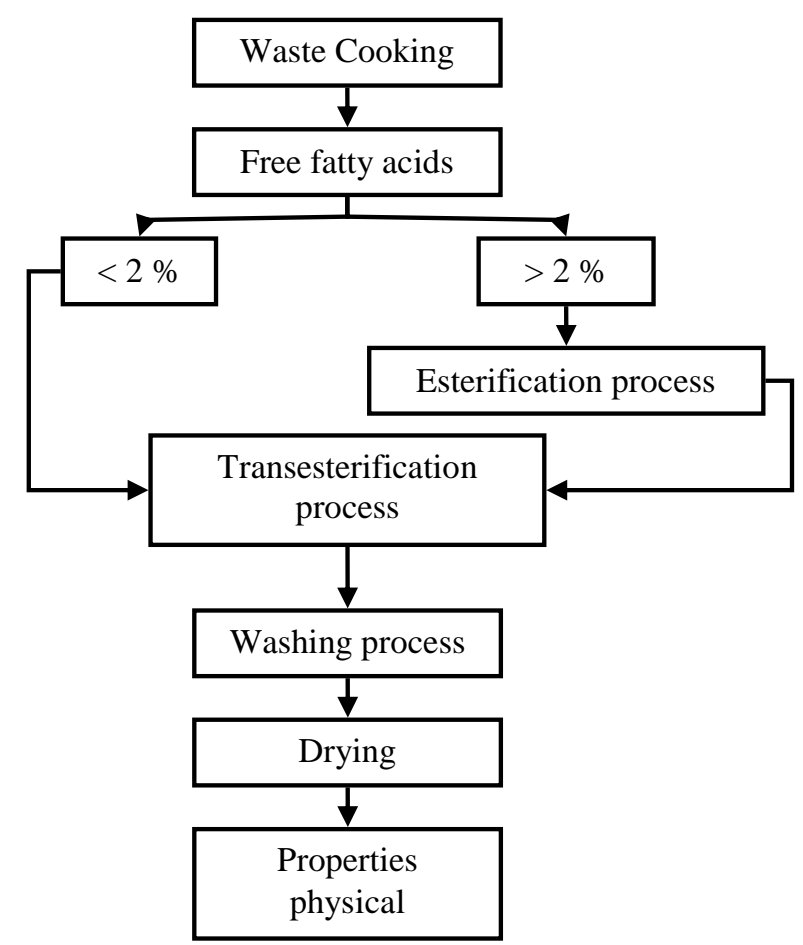

$[7,10]$
Feedstock Technical animal fats. Based on Fig. 1 it is recognized that the production of technical animal fats will be the function of the frying temperature and length of use as well as the material used for frying. In this experiment, TAF were collected from a local Factory, which produced chip cracker as well as continental foods. The used fat sample was taken from the fryer which is used for frying potatoes and other vegetables based food items. Twenty-five litters of fats samples were collected from a collecting drum in which the TAF was collect once in every days for approximately 1 weeks. The fats sample is assumed to be representative as it is collected from the fats stored for 8-10 weeks from several batches of waste fat. The temperature observed during frying was in the range of $110{ }^{\circ} \mathrm{C}$ to $155{ }^{\circ} \mathrm{C}$. This temperature is comparable with the temperature $\left(120{ }^{\circ} \mathrm{C} \ldots 170{ }^{\circ} \mathrm{C}\right)$ for preparing French fries [7-10]. However, it was found difficult to read the temperature in boiling fats which gives approximately 5-10\% error. Depending on the quantity of food used for frying, the fats was discarded sometimes at the end of each day and sometimes once in two or three days.

Free Fatty Acids. Flow chart in Fig. 1 shows the relation between FFA and process. Which FFA less than 2 $\%$, the process can directly to transesterification process and while FFA more than $2 \%$ it need to start from esterification process to reduce FFA. The acid value of the technical animal fats was determined in order to estimate the free fatty acid content and give an idea of how much acid catalyst and methanol would be needed to push the acid esterification chemical towards methyl ester production. In earlier published research it was recommended that $0.5-1.5 \%$ (based on the weight of free fatty acid in the fat) of pure (95-98\%) sulphuric acid should be used as a catalyst.

Acid value titration method was used according to BP monograph [9-10].

Processing in Biodiesel. Biodiesel has two main stage process is esterification and transesterification process. Separation was used to separate two layer between catalyze and fat. Washing process to produce the neutral biodiesel and remove catalyzes glycerol, soap and methanol.

1) Esterification. Based on flow chart in Fig. 1 esterification is one of process in biodiesel. It work to reduce FFA if FFA more than 2\%. An acid-catalyzed esterification process before the base-catalyzed transesterification process will eliminate most of the free fatty acids from the fat. Sulphuric acid $(95-98 \%)$ is used by $1 \%$ in esterification process depend from waste cooking. In these experiments the sulphuric acid was first mixed with methanol before adding to the waste cooking fat. After adding the methanol / sulphuric acid and technical animal fats the agitator speed were used to mix the solvents until they became murky. This was then heated to about $60{ }^{\circ} \mathrm{C}$ for 2 hours. A higher temperature or a faster stirring rate may push the acidic esterification equation to convert free fatty acid to methyl ester.

2) Separation 1. Separation needed 3hour to get the top methanol and bottom fats layers of the biodiesel. Two layers could clearly be seen in the successful basic esterification biodiesel. The top layer was mainly methanol. The bottom layer was mainly triglyceride 
product esterification after remove the water. These processes to reduce free fatty acid until below $2 \%$. The density of the methanol is less than the bottom triglyceride.

3) Transesterification. Transesterification process work as to reduce viscosity in biodiesel. This process can be directly if FFA less than $2 \%$ show in fig. 1 . Sodium hydroxide was used as catalyst in this process. The amount of catalyst had an impact in the conversion of esters during the transesterification process. The reaction was carried out using $1 \%$ of catalyst concentration. Before transesterification process Sodium hydroxide was first mixed with methanol together in one container before adding to the waste cooking fat. After adding the methanol / sodium hydroxide and technical animal fats the agitator speed were used to mix the solvents until they became murky. This was then heated to about $60{ }^{\circ} \mathrm{C}$ for 2 hours.

4) Separation 2. Transesterification process and any methanol evaporation the resultant biodiesels were left to lie for at least 8 hours. Separations were used to separate the top (methyl ester) and bottom (glycerol) layers of the biodiesel samples. Two layers could clearly be seen in the successful basic transesterification biodiesel samples. The top layer was mainly composed of free fatty acid methyl esters. The bottom deposit was mostly made up of glycerol, salts, soap, other impurities and excess methanol as it is a very polar compound i.e. it partitions more with polar glycerol as opposed to the non-polar methyl esters.

5) Washing. The top methyl ester layer was separated and removed from every production sample. The water washing process was then used on some of the biodiesel batches. Once separated from the glycerin the biodiesel is sometimes purified by washing gently with warm water to remove residual catalyst or soaps, dried, and sent to storage. In some processes this step is unnecessary. This is normally the end of the production process resulting in a clear amber-yellow liquid with a viscosity similar to petro diesel. In some systems the biodiesel is distilled in an additional step to remove small amounts of color bodies to produce a colorless biodiesel.

Esterification process:

Fig. 2 shows the separation between methanol and triglycerin

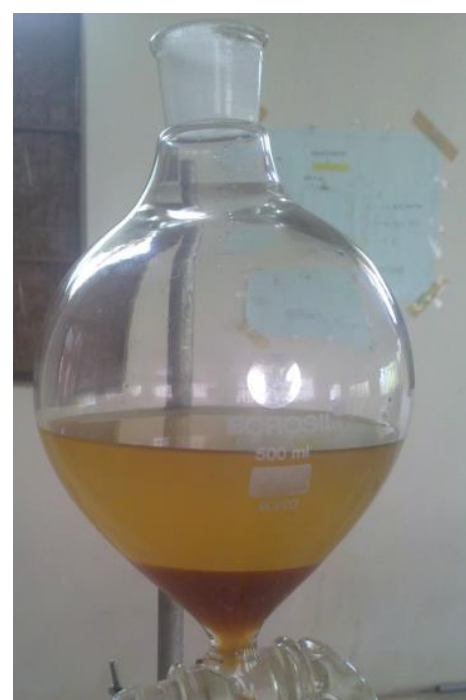

Fig. 2. Esterification process result [7].
- At the top will be presence methanol and at the bottom show triglycerin.

- Involves the reaction of alcohol (such as methanol) with fatty acids as catalyzed to reduce the levels of FFA in the low-cost feedstock's to an acceptable range.

- Reaction between acids and alcohols in the presence of strong acid catalyst.

- Produce ester and water free fatty acid of material must be less than $2 \%$.

It needs to use methanol and Sodium Hydroxide as catalyst:

- Fig. 3 show two layer separation between glycerol and FAME.

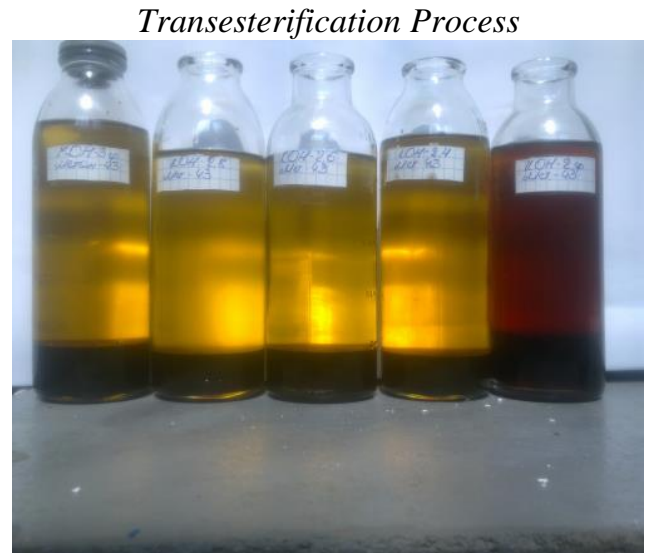

Fig. 3. Transesterification process result.

- Reduce the high viscosity of triglyceride ( TG ).

- Methanol and catalyst produce methyl ester and glycerol involves the reaction of alcohol (methanol) with fat.

Fig. 4 shows separation between water and FAME.

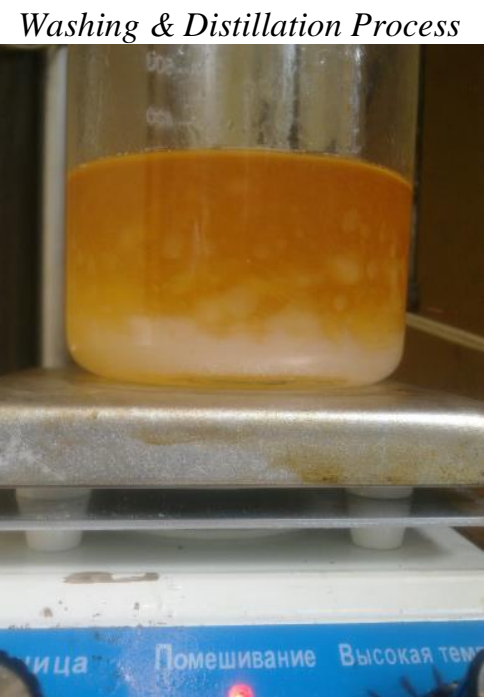

Fig. 4. Washing \& distillation process result.

- To remove small amounts of colour bodies to produce a colourless biodiesel it need washing many time

Biodiesel

- To obtain pure methyl esters (Biodiesel/ FAME)

- To remove soap, catalyst, methanol and other pollutants of biodiesel, using water

- If the washing is not complete, it will be repeated by esterification and transesterification or washing. 
- At the top will be presence FAME and the at bottom is glycerol.

- Reduce the high viscosity of triglyceride ( TG ).

- Methanol and catalyst produce methyl ester and glycerol involves the reaction of alcohol (methanol) with fat.

Fig. 4 shows separation between water and FAME.

- To remove small amounts of colour bodies to produce a colourless biodiesel it need washing many time

Biodiesel

- To obtain pure methyl esters (Biodiesel/ FAME)

- To remove soap, catalyst, methanol and other pollutants of biodiesel, using water

- If the washing is not complete, it will be repeated by esterification and transesterification or washing.

- Biodiesel can show in fig. 5 which left is raw material and right is biodiesel.

- The percentage of biodiesel around $68-70 \%$ can be produce.

- Increase in the molar ratio the conversion of TAF to FAME decrease.
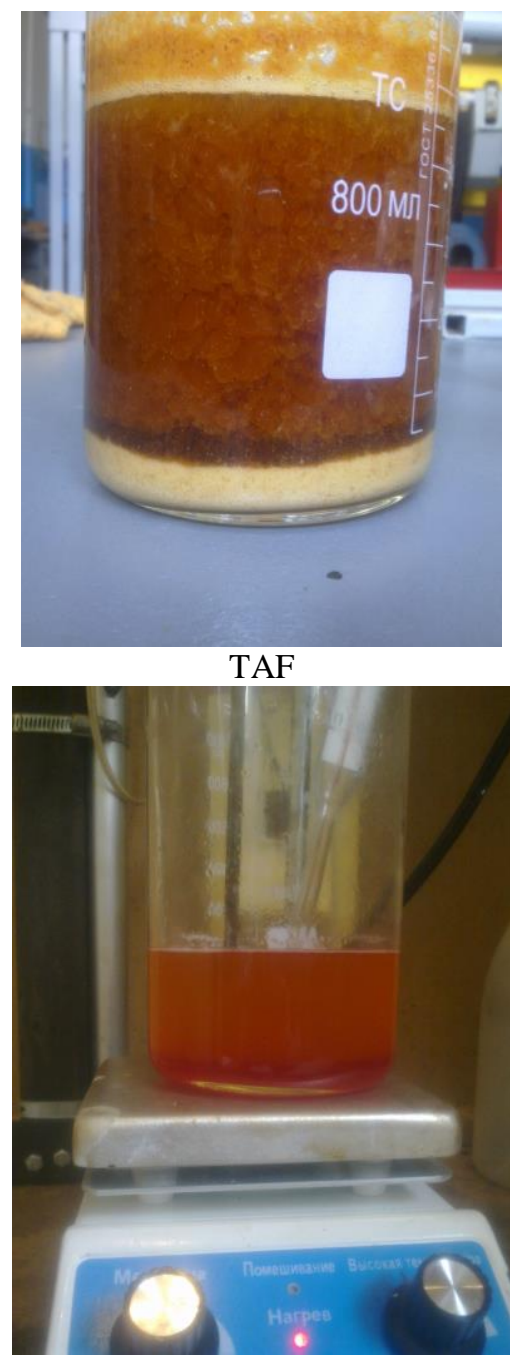

Biodiesel

Fig. 5. TAF to biodiesel [7].

- At the same time, the waste can be converted to useable energy, pollution due to technical animal fats can be avoided, and energy can be continuously saved and renewed.
Drying. After washing water still have inside biodiesel. Then the water must be removed from the biodiesel using drying at $120{ }^{\circ} \mathrm{C}$ for 24 hour.

Properties are one of method to determine the standard of biodiesel. Biodiesel can check using density, viscosity, flash point, acid value and water content.

Equipment for testing kinematic viscosity and Standard method for kinematic viscosity is Kinematic viscosity DSTU 6081:2009 and EN 14214:2003 [5-6], 40 ${ }^{\circ} \mathrm{C}$, requirement: $1.9-6.0 \mathrm{~mm}^{2} / \mathrm{s}$. Kinematic viscosity: "the resistance to flow of a fluid under gravity". The kinematic viscosity is equal to the dynamic viscosity/density the kinematic viscosity is a basic design specification for the fuel injectors used in diesel engines. Too high a viscosity and the injectors do not perform properly. Dynamic viscosity - (ratio between applied shear stress and rate of shear of a liquid). Density - "the mass per unit volume of a substance at a given temperature." The viscosity of biodiesel can be predicted $\pm 15 \%$ using the esters composition determined using DSTU 6081:2009. The viscosity apparatus to run D 445 is not critical to the QC laboratory, but it is valuable as a quick assay method for estimating the degree of completion for a reaction batch [5-6].

Equipment for testing combustion in biodiesel using method ASTM D93- Flash point, closed cup, requirement $130{ }^{\circ} \mathrm{C}$ min. The flash point is defined as the "lowest temperature corrected to a barometric pressure of $101.3 \mathrm{kPa}(760 \mathrm{~mm} \mathrm{Hg})$, at which application of an ignition source causes the vapors of a specimen to ignite under specified conditions of test."

Testing for acid value using method DSTU 6081:2009 - Acid number, requirement $0.80 \mathrm{mg} \mathrm{KOH} / \mathrm{g}$. The acid number is "The quantity of base, expressed as milligrams of potassium hydroxide per gram of sample, required to titrate a sample to a specified end point." The acid number is a direct measure of free fatty acids in B100. The free fatty acids can lead to corrosion and may be a symptom of water in the fuel. Usually, for a base catalyzed process, the acid value after production will be low since the base catalyst will strip the available free fatty acids. However, the acid value may increase with time as the fuel degrades due to contact with air or water. This test should be performed regularly as a part of the producer QC program [5-6].

This testing is very important in biodiesel. Before biodiesel are use in the engine water content must be follow the standard to avoid damage. The standard DSTU method D2709 is max $0.005 \%$ [5-6].

\section{Conclusions}

1. The biodiesel was prepared from technical animal fats sample collected from a local factory in Ukraine. The biodiesel was characterized for its physical and fuel properties using DSTU and EN standard methods for biodiesel fuel quality assurance.

2. The composition of final biodiesel was determined by physical properties such as density, viscosity, flash point, water content and acid value. From the tests, the flash point was found to be $97{ }^{\circ} \mathrm{C}$, water and sediment was $0.02 \%$, total acid number was $0.29 \mathrm{mg} \mathrm{KOH} / \mathrm{g}$, 
viscosity at $40{ }^{\circ} \mathrm{C}$ was $4.2 \mathrm{~mm}^{2} / \mathrm{sec}$ and density $0.82 \mathrm{~g} / \mathrm{cm}$. Out of 5 properties tested, all of them met the DSTU criteria for fuel standard.

3. Production of biodiesel from waste cooking fats for diesel substitute is particularly important because the increasing cost of fats extracted from petroleum source and also it is good for environment. Technical animal fats can be an important source for biodiesel production in Ukraine it is ready available and environment.

\section{References}

1. Malyarenko, V. A., Yakovlev, A. I. (2016). Biodiesel-alternative to diversification of motor fuels. Energy saving. Power engineering. Energy audit. №. 3. 64-73.

2. Sukhenko, Yu., et al. (2017). Changing the quality of ground meat for sausage products in the process of grinding. Eastern European Journal of Enterprise Technologies. 2017. Vol. 4. 11 (88), 56-63.

3. Kovalenko, G. A., et al. (2015). Heterogeneous biocatalysts for transesterification of vegetable fat triglycerides into valuable oil and fat products and biodiesel. Biotechnology: the state and prospects of development. 351-352.

4. Rudnev, V. A., Maslov, I. V., Eliseev, V. V. (2018). Analysis of the possibility of using biofuels from vegetable oils. Actual problems and prospects of development of construction, heat supply and power supply. 107-110.

5. DSTU 6081:2009. Documentation - Presentation of theses and similar documents.

6. EN 14214:2003. Documentation - Presentation of theses and similar documents

7. Mushtruk, M. M. (2014). Grounding the characteristics of equipment for the production of liquid biofuels from technical animal fats. Kyiv, 234.

8. Zhu, L. D., Li, Z. H., Hiltunen, E. (2016). Strategies for lipids production improvement in microalgae as a biodiesel feedstock. BioMed research international. 23 - 29.

9. Kapor N. Z. et al. (2017). Palm fatty acid distillate as a potential source for biodiesel production-a review. Journal of cleaner production. Vol. 143. 1-9.

10. Mushtruk M. M., Sukhenko V. Y., Sukhenko Y. G. (2016). Biodiesel production and properties: monograph / Ed. by doc. of Tech Sc V.Y. Sukhenko. Kyiv: CP "Komprint", 252.

\section{Список літератури}

1. Маляренко В. А., Яковлев А. И. Биодизельальтернатива диверсификации моторных топлив. Энергосбережение. Энергетика. Энергоаудит. 2006. №. 3. C. 64-73.

2. Sukhenko Yu., Sukhenko V., Mushtruk M., Vasuliv V., Boyko Y. Changing the quality of ground meat for sausage products in the process of grinding. Eastern European Journal of Enterprise Technologies. 2017. Vol. 4. 11(88), P. 56-63.
3. Коваленко Г. A. $u$ дp. Гетерогенные биокатализаторы для переэтерификации триглицеридов растительных масел в ценные масложировые продукты и біодизель. Биотехнология: состояние и перспективы развития. 2015. С. 351-352.

4. Руднев В. А., Маслов И. В., Елисеев В. В. Анализ возможности использования биотоплива из растительных масел. Актуальные проблемы и перспективы развития строительства, теплогазоснабжения и энергообеспечения. 2018. C. 107-110.

5. DSTU 6081:2009. Documentation - Presentation of theses and similar mdocuments.

6. EN 14214:2003. Documentation - Presentation of theses and similar documents

7. Муштрук М. М. Обгрунтування характеристик обладнання для виробництва рідкого біопалива 3 технічних тваринних жирів: дис. ... к - та техн. наук: 05.18.12. Нац. унів. харч. техн. Київ, 2014. 234 с.

8. Zhu L. D., Li Z. H., Hiltunen E. Strategies for lipid production improvement in microalgae as a biodiesel feedstock. BioMed research international. 2016. P. 23-29.

9. Kapor N. Z. et al. Palm fatty acid distillate as a potential source for biodiesel production a review. Journal of cleaner production. 2017. T. 143. P. 1-9.

10. Mushtruk M.M., Sukhenko V.Y., Sukhenko Y.G. Biodiesel production and properties: monograph. Ed. by Doc. of Tech. Sc. V.Y. Sukhenko. Київ: ЦП «Компринт», 2016. 252 p.

\section{ДОСЛІДЖЕННЯ ПРОЦЕСУ ВИРОБНИЦТВА ДИЗЕЛЬНОГО БІОПАЛИВА $З$ ТЕХНІЧНИХ ЖИРІВ М. М. Муштрук}

Анотація. Попередньо очищені технічні тваринні жири шкідливі для здоров'я, так як вони не $\epsilon$ екологічно чистими, і не придатні для утилізації. Найкращим рішенням $\epsilon$ їх використання для промислових цілей, а саме перетворення в дизельне біопаливо. Метою даного дослідження $\epsilon$ удосконалення технології виробництва дизельного біопалива 3 технічних тваринних жирів в лабораторних умовах та проведенням випробувань отриманих зразків. Розглянуто найбільш важливі операції технологічного процесу отримання біодизелю 3 відходів тваринних жирів. Оцінений вплив якості жирової сировини на склад рідкого біопалива та розроблені вихідні вимоги до сировини. Встановлено, що вологість сировини має визначальний вплив на механізм переестерифікації тригліцеридів у метилові ефіри жирних кислот, які за експлуатаційними характеристиками близькі до нафтового дизельного палива. Вільні жирні кислоти у сировині в поєднанні з водою роблять технологічний процес не ефективним. У результаті наукових досліджень обгрунтовано технологію виробництва дизельного біопалива 3 відходів рослинних олій i тваринних жирів та запропоновано іiі апаратурне забезпечення. За результатами лабораторних досліджень встановлено можливість одержувати якісний продукт, що відповідає сучасним експлуатаційним вимогам до дизельного біопалива, 
яке можна використовувати у двигунах без суттєвого їх переобладнання.

Ключові слова: дизельне біопаливо, технічні тваринні жири, сировина, етерифікація, сепарація, переетерифікація, альтернативні енергоресурси, технологія виробництва, стандарт.

\section{ИССЛЕДОВАНИЕ ПРОЦЕССА ПРОИЗВОДСТВА ДИЗЕЛЬНОГО БИОТОПЛИВА ИЗ ТЕХНИЧЕСКИХ ЖИРОВ \\ М. М. Муштрук \\ Аннотация. Предварительно очищенные} технические животные жиры вредны для здоровья, так как они не являются экологически чистыми и не пригодны для утилизации. Лучшим решением является их использование для промышленных целей, а именно преобразования в дизельное биотопливо. Целью данного исследования является совершенствование технологии производства дизельного биотоплива с технических животных жиров в лабораторных условиях и проведение испытаний полученных образцов. Рассмотрены наиболее важные операции технологического процесса получения биодизеля из отходов животных жиров. Оценено влияние качества жирового сырья на состав жидкого биотоплива и разработаны исходные требования к сырью. Установлено, что влажность сырья имеет определяющее влияние на механизм переэтерификации триглицеридов в метиловые эфиры жирных кислот, которые по эксплуатационным характеристикам близки к нефтяному дизельного топлива. Свободные жирные кислоты в сырье в сочетании с водой делают технологический процесс не эффективным. В результате научных исследований обоснована технология производства дизельного биотоплива из отходов растительных масел и животных жиров и предложено ее аппаратурное обеспечение. По результатам лабораторных исследований установлена возможность получения качественного продукта, который отвечает современным эксплуатационным требованиям к дизельным биотопливам, которое можно использовать в двигателях без существенного их переоборудование.

Ключевые слова: дизельное биотопливо, технические животные жиры, сырье, этерификация, сепарация, переэтерификация, альтернативные энергоресурсы, технология производства, стандарт.

M. M. Mushtruk ORCID 0000-0001-8487-2153. 